\title{
THE ROLE AND THE RESPONSIBILITY OF THE ARCHITECT IN THE CURRENT AND FUTURE SUSTAINABLE DESIGN OF BUILDINGS
}

\section{ALEŠ MAREK}

Czech Technical University in Prague, Faculty of Architecture, Thákurova 9, 16634 Prague 6 - Dejvice, Czech republic

Tutor: prof. Ing. Miloslav Pavlík, CSc.

Theme of the dissertation: The role of the architect in the process of project preparation of buildings by the BIM method ales.marek@fa.cvut.cz

\begin{abstract}
This paper deals with the role and responsibility of the architect in the sustainable design of buildings in their lifelong cycle: in construction, operation, modernisation, and removal. The aim is to analyse and define requirements for the architect's activities in the design stages. The paper discusses the demands and methods of integrated design, digitisation and robotics in the construction industry, and the use of BIM. The starting point is design practice and international requirements for the complex evaluation of buildings.
\end{abstract}

KEY WORDS: sustainability, integrative design, LEED, BIM, Building Information Model, Digital Building Information Model, Common Data Environment

\section{The goal}

The aim of this paper is to highlight the main ways in which an architect can influence the sustainability of a building during the design process.

\section{Starting point}

My paper is based on:

1. my own experience in design practise for more than 30 years, including 10 years of BIM use, and earning two LEED Platinum certificates on my projects: 
1.1. Main Point Karlín(1), Prague 8, 38.000 sqm above ground, certified 2012, where a flushing channel from the Vltava River was employed for cooling of the building.

1.2. CSOB Headquarters - SHQ(2), Prague 5, 67.400 sqm above ground, certified 2019 (6. - 8. place in Europe), where the biggest drilling field in the Czech Republic (177 drills, $150 \mathrm{~m}$ long) was designed and constructed, covering all the needs for cooling and heating supply, which is $60 \%$ lower than the LEED reference building.

2. Evaluation of 28 BIM projects I have processed in the years 2011-21.

\section{The Hypothesis}

There is no difference between the design process concerning a green building and a normal one.

The change is that certification, or rather pre-certification, requires having specific data earlier than usual, i.e., in the Concept Design stage, to prepare the certification process, but what is crucial is to also implement certification demands in the overall design.

\section{The Methodology}

Regarding the format of the paper, I decided to address the main design demands with the focus solely on the architect's key activity, i.e., steering the entire design team, and to briefly describe the design processes' milestones, which suit not only the architect's designing method, but also that of the entire design team.

The conclusions are based not only on an internal evaluation of the quality of the design processes of AED project, a.s., but mainly on recent design experience, when requirements for sustainable designing already appear in architectural competitions, e.g., SZ Headquarters in Prague(3).

\section{Contemporary architectural design highlights}

The one thing all humans share is that we all inhabit the same limited amount of real estate, which is Planet Earth.(4)

Architectural design must be elaborated in accordance with the principles of economic, social, and environmental sustainability.

I consider the following design points as the most important ones:

1. seek harmony in the architectural design, venustas - aesthetic objective, the 
construction and technical equipment of the building, firmitas - static strength and stability, and the use value of the building, utilitas - practical objective(5), throughout its life cycle

2. seek harmony between the indoor and outdoor parts of the projects

3. apply the philosophy of integrated design, including sustainable design requirements

4. reap the benefits of digitisation and BIM in the design process to verify the design via expert assessments (dynamic simulation etc.) from the early design phases

5. use the score chart of any registered international sustainability certification system to find a positive compromise in the building design itself, and between the design and certificate target, if required

This approach brings the following benefits:

1. maximising the exploitation of the site potential, including the use of local materials and greenery for construction and project integration into local public transport services

2. minimising energy consumption and maximising use of renewable energy sources, including water conservation, rainwater harvesting and minimal operating and maintenance costs

3. reducing global overheating by avoiding the creation of heat islands

4. creating a high-quality indoor environment to improve the health and psychological well-being of its occupants

\section{The architect's approach to integrative design}

The architect, as the leader of the entire design team, has a moral and professional responsibility for the design quality of the building during the design stage, because it substantially affects all the related stages of the building's life cycle(6).

Architects must know the whole issue of designing buildings. To understand the whole, one must understand the pieces. But, in this capacity, architects must be sure they do not dive too deeply into partial problems. They must keep their energy and time capacity to find a positive compromise in the overall design.

The architect's main task is to balance all architectural, operational, and technical requirements.

At the beginning of the design process, the architect must assemble a complete design team, i.e., all key professions, specialists, and consultants, for all design phases. 
During the design process, the architect must honestly consider all suggestions and proposals from the design team, even if they seem at first sight either unfeasible or obvious.

The same approach must be applied to suggestions that do not correspond to the project's development phase at that time.

The architect is responsible for evaluating all the suggestions of each design phase and for setting goals for the next phase. This should be repeated during each phase.

This process, with the same demands, is the same as in the proper BIM design methodology.

\section{The architect's design using the certification system}

Certification assesses the impact on the environment, water and energy consumption, materials used, quality of the indoor environment and the user qualities required to work efficiently.

As a showcase, I am presenting herewith the LEED Project Checklist which can help architects to develop a project design balanced in all aspects.

Below are selected credits in which architects can substantially influence the sustainability of a building.

LEED v4.1 for BD+C: New Construction and Major Renovation: Project Checklist(7):

- Integrative Process

- Location and Transportation: Sensitive Land Protection, Bicycle Facilities

- Sustainable Sites: Open Space, Heat Island Reduction, Light Pollution Reduction

- Water Efficiency: Outdoor Water Use Reduction

- Energy and Atmosphere: Minimum Energy Performance

- Materials and Resources: Construction and Demolition Waste Management

- Indoor Environmental Quality: Low-Emitting Materials, Interior Lighting, Daylight, Quality Views, Acoustic Performance

- Innovation

The certification system has no artificial intelligence to design a building on your behalf. It provides you with reasonable guidelines for organising, steering, and balancing the design process in the complex view. 


\section{BIM}

I have evaluated 28 BIM projects according to the following criteria:

a) Use of the Sub Models:

Architectural Sub model:

$5 \quad 8 \%$

Construction Sub model:

$28 \quad 44 \%$

Structural Sub model:

$11 \quad 17 \%$

MEP sub model:

$1422 \%$

Sub model of Technologies:

$6 \quad 9 \%$

ß) Service Phases Processed by the BIM method:

SP1 Project Initiation:

$\begin{array}{rr}9 & 10 \% \\ 4 & 4 \%\end{array}$

SP2 Preliminary - Concept Design:

SP3 Land Zone Permit Design:

$4 \%$

SP4 Building Permit Developed Design:

$28 \%$

SP5 Detailed Design:

$25 \%$

SP6 List of Works and Deliverables:

$23 \%$

SP7 Architect's Supervision:

The design data for certification, comparing to non-certified buildings, are supplemented according to the final checklist score chart.

For the certification process, it is crucial to have data structured according to the certification system at the right time, i.e., Concept Design stage, to be possible to make a fully informed decision - value engineering - regarding the next project phase specification.

The BIM method helps you to easily extract required data from the Information model.

It is clear from the above tables that there is a need for architects, and all consultants, to use the BIM method in all projects where green certification is required, and therefore the information modelling must start at the Concept Design stage.

\section{Summary}

"Integrity is the essence of everything successful."(8)

\section{Annex}




\section{Footnotes}

1. DAM ARCHITEKTI

2. CHALUPA ARCHITEKTI

3. https://www.spravazeleznic.cz/web/en/headquarters

4. INGELS, BJARKE

5. MARCUS VITRUVIUS POLLIO: Ten Books on Architecture, 1st century BC.

6. Life-long Cycle

7. https://www.usgbc.org/leed/v41

8. FULLER, BUCKMINSTER 


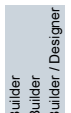

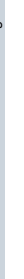 \\ 列}

IIII

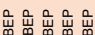

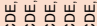

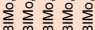

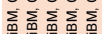

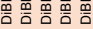

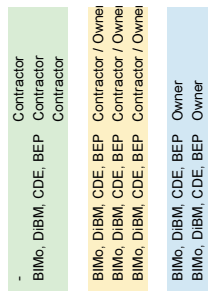

.
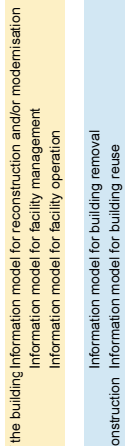

胥

ธั.

亭
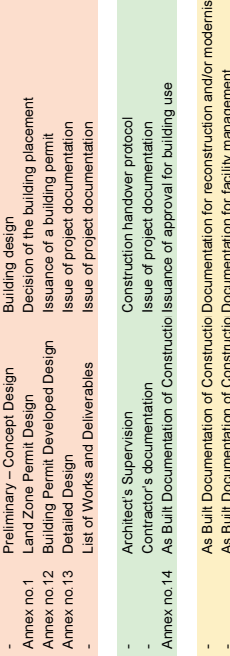

홓
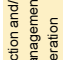

号

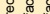

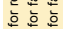

들 흘

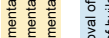
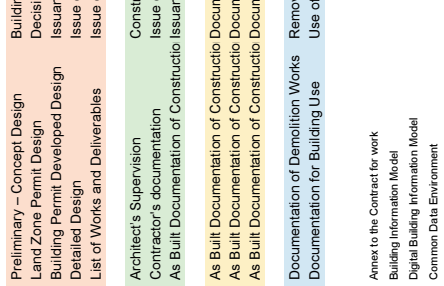

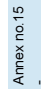

흥 